
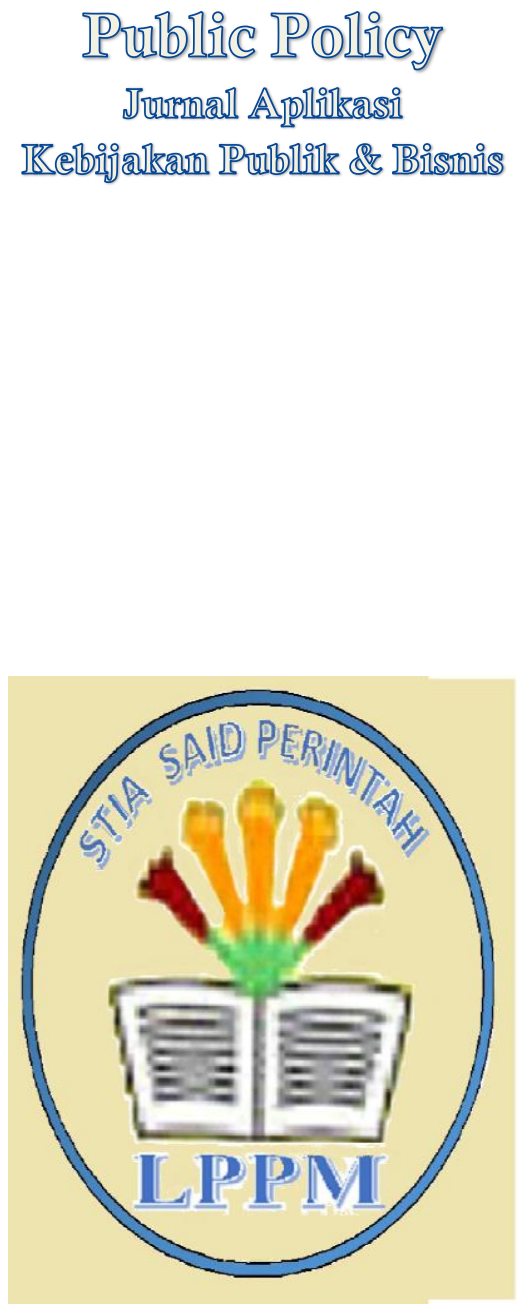

Volume 1, No. 1, Maret 2020

LPPM STIA Said Perintah

\section{Pengaruh Motivasi Kerja Terhadap Kinerja Pegawai Pada Kantor Kecamatan TNS Kabupaten Maluku Tengah}

Hendry Ch. Soselisa

Program Studi Administrasi Negara STIA Said Perintah hendry_soselisa@yahoo.co.id

Mariana Killay

Program Studi Administrasi Negara STIA Said Perintah killay@gmail.com

\begin{abstract}
This study aims to discuss and analyze the Work Motivation of Employee Performance in the District Office of Teon Nila Serua, Central Maluku Regency. The benefit of this research is that it provides information about the Effect of Work Motivation on Employee Performance at the District Office of Teon Nila Serua, Central Maluku Regency.

The results this hypothetical test of work motivation is significant for employee performance. Therefore the results of this study state that work motivation has a good relationship with employees, increasing employee work motivation is expected to obtain higher performance as well. On this basis work motivation variable $(X)$ can be included as one variable requested for employee performance $(Y)$ in the Teon Nila Serua District Office of Central Maluku Regency.
\end{abstract}

Keywords : Work Motivation, Employee Performance

stia-saidperintah.e-journal.id

\section{Latar Belakang}

Pengembangan sumber daya manusia dan organisasi merupakan suatu proses peningkatan kualitas dan kapasitas pegawai saat ini untuk mencapai tujuan organisasi. Tujuan organisasi dapat dicapai apabila didukung oleh kinerja yang baik dari para pegawai tersebut. Pengembangan sumber daya manusia (SDM) secara mikro, pada hakekatnya adalah upaya untuk merencanakan, meningkatkan kemampuan dan mengolah tenaga kerja atau pegawai, sehingga diperoleh kinerja yang tinggi.

Sebuah organisasi memerlukan manusia sebagai sumber daya manusia yang berkualitas akan terus memajukan organisasi sebagai suatu wadah peningkatan kinerja pegawai. Maka, untuk 
mewujudkan tujuan organisasi termasuk organisasi pemerintah, setiap pegawai dituntut untuk bekerja secara maksimal sehingga dapat memuaskan para pelanggan (masyarakat). Hal tersebut karena memang esensi kehadiran sebuah organisasi pemerintahan dalam rangka memberikan pelayanan kepada masyarakat (public service). Sumber Daya Manusia yang dimiliki suatu instansi ini salah satunya adalah pegawai, sehingga untuk dapat meningkatkan kualitas suatu instansi dibutuhkan pegawai-pegawai yang berkualitas. Adanya standar kualitas pegawai ini nantinya akan menjadi acuan bagi masing-masing pegawai dalam menunjukkan kinerja yang dimiliki untuk menyelesaikan pekerjaan yang dilakukan serta sebagai tolak ukur bagi pimpinan dalam melakukan penilaian kinerja dari pegawai yang bersangkutan.

Usaha untuk mendapatkan kinerja pegawai yang optimal, seorang pimpinan tidak cukup hanya dengan meyakinkan bahwa pegawai bersangkutan mempunyai pengetahuan dan keterampilan, tetapi disamping itu seorang pimpinan juga harus dapat memahami motivasi kerja pegawai, mendorong dan mengarahkan potensipotensi yang ada serta memahami hal-hal yang dapat melahirkan kepuasan kerja. Untuk itu diperlukan pendekatan yang relevan dan pembinaan-pembinaan secara lebih manusiawi.

Kinerja adalah kerja secara kualitas dan kuantitas yang dicapai oleh seorang pegawai dalam melaksanakan tugas yang diberikan kepadanya. Suatu organisasi baik pemerintahan maupun swasta dalam mencapai tujuannya harus melalui orangorang yang berperan aktif sebagai pelaku pencapaian tujuan tersebut. Untuk mencapai tujuan tersebut maka setiap individu yang berada di dalam organsasi tersebut harus meningkatkan kinerjanya, sehingga secara langsung akan meningkatkan kinerja organisasi tersebut.

Pendapat lain oleh Tamaela Eduard \& Surijadi Herman, (2014) menyatakan bahwa kinerja adalah hasil kerja yang telah dilakukan sesorang dalam melaksanakan tugas dan pekerjaan yang dibebankan kepadanya.

Berhadapan dengan usaha peningkatan kinerja pegawai, salah satu permasalahan dasar adalah menciptakan lingkungan kerja yang baik serta meningkatkan motivasi kerja pegawai. Kedua hal ini berperan dalam meningkatkan efektivitas dan efesiensi dari organisasi didalam menjalankan seluruh kegiatan dan pekerjaan yang telah direncanakan dan diprogramkan. Dengan lingkungan kerja yang baik dan motivasi yang tinggi, bagi 
pegawai diharapkan dapat meningkat kinerjanya guna mewujudkan visi misi organisasi tempat mereka bekerja.

Faktor yang berperan dalam peningkatan kinerja pegawai adalah motivasi kerja. Motivasi adalah sesuatu yang menimbulkan semangat atau dorongan kerja, untuk itu motivasi kerja didefinisikan sebagai keadaan dalam pribadi seseorang yang mendorong keinginan individu untuk melaksanakan kegiatankegiatan untuk mencapai tujuan. Dengan demikian pemberian motivasi juga berarti memberikan kesempatan kepada pegawai untuk mampu mengembangkan kemampuan dan merupakan dorongan semaksimal mungkin bagi pegawai untuk berproduksi.

Pemberian motivasi berupa jaminan keselamatan kerja dan kesejahteraan pegawai mampu mengembangkan kompetensi dan merupakan dorongan semaksimal mungkin untuk pegawai berprestasi. Sedangkan disiplin dimaksudkan kesadaran dan kesediaan sesorang mentaati semua ketentuan dan peraturan-peraturan yang berlaku. Selain itu kesadaran yang dimulai dari sikap seseorang secara sukarela dalam mentaati semua peraturan dengan sadar akan tugas dan tanggung jawabnya, sehingga dia akan mematuhi/mengerjakan tugas dengan baik bukan atas paksaan.

Motivasi kerja yang terjadi, pada Kantor Kecamatan TNS Kabupaten Maluku Tengah dilihat dari motivasi kerja pada pegawai yang ada dalam instansi tersebut yaitu adanya pegawai yang kurang mampu berprestasi dalam meningkatkan kerjanya dalam melakukan tugas yang diberikan kepadanya untuk dikerjakan. Terkadang tugas yang harus mereka kerjakan, mereka membutuhkan bantuan dari pegawai lain atau rekan sekerja untuk menyelesaikan tugas tersebut.ini menandakan pegawai tidak adanya motivasi dari pegawai tersebut untuk berprestasi dalam mengerjakan suatu tugas yang diberikan kepadanya. Selain itu terkadang juga, kurangnya pemahaman yang merata tentang job description yang seharusnya diketahui oleh pegawai tersebut dalam melaksanakan tugas dan tanggung jawabnya. Kurangnya pemahaman yang baik dan dengan didorong oleh kurangnya kesadaran dalam menyelesaikan tanggung jawab yang diberikan untuk dikerjakan mengindikasikan bahwa pegawai tidak berusaha untuk pengembangan diri untuk kearah yang lebih baik, dalam memotivasi dirinya untuk berprestasi dalam melaksanakan tugas yang di kerjakannya.

Keberadaan organisasi pemerintah, seperti halnya pada Kantor Kecamatan TNS 
Kabupaten Maluku Tengah memiliki peran yang penting terutama bagi terwujudnya tata kelola pemerintahan yang baik dan bersih, dibidang kegiatan yaitu, penyusunan dokumentasi standar satuan harga, penyusunan dokumentasi standar biaya masukan,penyusunan standar personil dan non personil, penyusunan dokumentasi analisa standar belanja. Kantor Kecamatan TNS sebagai salah satu sub sistem kelembagaan Pemerintah Kabupaten Maluku Tengah yang merupakan satuan organisasi di lingkungan pemerintah Daerah Kabupaten Maluku Tengah, yang memperhatikan prinsip koordinasi, integrasi, dan sinkronisasi.

Kinerja pegawai tercapai apabila pihak Kantor Kecamatan TNS Kabupaten Maluku Tengah memperhatikan hal-hal yang berhubungan dengan lingkungan kerja agar pegawai dapat melaksanakan tugas dan tanggung jawabnya dengan situasi yang kondusif. Selain itu, pihak Kantor Kecamatan TNS Kabupaten Maluku Tengah juga perlu terus berupaya meningkatkan motivasi kerja para pegawainya sehingga memiliki keinginan dan kesediaan untuk berprestasi, dengan beberapa perlakuan seperti mendapatkan pengakuan dari pimpinan dan rekan sekerja, kejelasan uraian tugas, keinginan, kesempatan dan kejelasan kebijakan yang berhubungan dengan usaha pengembangan diri pegawai. Disisi lain, sebagian pegawai belum sepenuhnya dapat melaksanakan tanggung jawab, disiplin dan belum tepat waktu menyelesaikan pekerjaan yang tercermin pada adanya tunggakan kerja.

Fenomena tersebut merupakan salah satu dari sekian banyak fakta yang terjadi dan diduga ada kaitannya dengan lingkungan kerja yang kurang mendukung serta motivasi kerja para pegawai yang kurang dalam melaksanakan pekerjaannya sehingga kinerja pegawainya dikatakan kurang baik. Namun hal tersebut masih perlu diteliti lebih lanjut melalui penelitian empiris dengan judul "Pengaruh Motivasi Kerja Terhadap Kinerja Pegawai Pada Kantor Kecamatan TNS Kabupaten Maluku Tengah".

\section{Tinjauan Pustaka}

Berdasarkan latar belakang dan rumusan masalah yang telah dijelaskan pada bab sebelumnya, pada bab ini akan mengkaji teori - teori yang relevan dengan variabel - variabel penelitian dan publikasi umum yang ada hubungannya dengan Sumber daya manusia, motivasi kerja dan kinerja pegawai, untuk dijadikan landasan teori dalam pelaksanaan penelitian ini. Menurut Sugiyono, (2012) bahwa kajian pustaka adalah suatu kegiatan penelitian 
yang bertujuan melakukan kajian secara sungguh-sungguh tentang teori-teori dan konsep-konsep yang berkaitan dengan topik yang akan diteliti.

Manajemen Sumber Daya Manusia merupakan ilmu dan seni yang mengatur hubungan dan peranan tenaga kerja agar efektif dan efisien membantu terwujudnya tujuan perusahaan. Manajemen yang mengatur unsur manusia ini sering disebut manajemen kepegawaian atau manajemen personalia yang diterapkan pada suatu perusahaan untuk mencapai tujuan yang diinginkan.

Menurut Anwar Prabu Mangkunegara, (2013) bahwa,

"Manajemen sumber daya manusia merupakan suatu perencanaan, pengorganisasian, pengkoordinasian, pelaksanaan, dan pengawasan terhadap pengadaan, pengembangan, pemberian balas jasa, pengintegrasian, pemeliharaan, dan pemisahan tenaga kerja dalam rangka mencapai tujuan organisasi".

Berdasarkan beberapa pengertian Manajemen Sumber Daya Manusia diatas maka dapat dilihat bahwa Manajemen Sumber Daya Manusia adalah suatu penerapan fungsi-fungsi perencanaan, pengelolaan, pengarahan, dan pengawasan sumber daya manusia yang ada di dalam perusahaan dan fungsi tersebut digunakan untuk melaksanakan tindak pengadaan, pengembangan, pemeliharaan, dan pendayagunaan sumber daya manusia.

Sehubungan dengan itu Omolo, (2015) menyatakan bahwa motivasi adalah kunci dari organisasi yang sukses untuk menjaga kelangsungan pekerjaan dalam organisasi dengan cara dan bantuan yang kuat untuk bertahan hidup. Motivasi adalah memberikan bimbingan yang tepat atau arahan, sumber daya dan imbalan agar mereka terinspirasi dan tertarik untuk bekerja dengan cara yang anda inginkan.

Teori Motivasi telah dibahas dan dikonsep oleh berbagai peneliti. Tingkat motivasi seorang individu atau tim diberikan dalam tugas atau pekerjaan mereka yang dapat mempengaruhi semua aspek kinerja organisasi. Dalam penelitian terbaru, motivasi didefinisikan oleh Eduard $Y$. Tamaela \& V. R. Pattipeilohy, (2015) yang menyatakan bahwa motivasi merupakan proses pemberian motiv kepada bawahan sedemikian rupa sehingga bawahan tersebut dapa bekerja dengan baik untuk mencapai tujuan perusahaan.

Berdasarkan beberapa pendapat yang dikemukakan oleh para ahli dapat disimpulkan bahwa motivasi kerja adalah suatu proses dimana kebutuhan mendorong seseorang untuk melakukan serangkaian kegiatan yang mengarah ke tercapainya tujuan tertentu dan tujuan organisasi dan 
untuk memenuhi beberapa kebutuhan. Kuat lemahnya motivasi kerja seorang tenaga kerja ikut menentukan besar kecilnya prestasi kerja.

Konsep motivasi kerja yang digunakan dalam penelitian ini adalah berasal dari teori Herzberg. Khususnya pada komponen 'Motivators' dari Herzberg adalah meliputi; achievement, recognition , work-itself, responsibility dan advancement (Fred Luthans, 2002).

Kelima dimensi motivasi kerja inilah yang kemudian digunakan dalam penelitian ini. Sesuai penjelasan Fred Luthans, (2002) kelima komponen motivator tersebut sebagai berikut:

1) Achievement, hal ini menyangkut tentang dorongan dan kesempatan seseorang pegawai/karyawan untuk berprestasi pada tugas tertentu. Artinya, suatu tugas/pekerjaan harus memungkinkan bagi seseorang pegawai/karyawan sebagai pelaksana tugas/pekerjaan tersebut untuk mencurahkan kemampuannya dalam mencapai prestasi tertentu.

2) Recognition; hal ini menyangkut pengakuan dari pimpinan dan rekan sekerja. Artinya, seseorang akan termotivasi untuk bekerja apabila ada pengakuan diri atau penghargaan dari pimpinan dengan rekan sekerjanya.
3) Work-itself, hal ini menyangkut tentang kejelasan uraian tugas; dan dukungan orang lain (pimpinan dan rekan sekerja) dalam melaksanakan tugas/pekerjaan.

4) Responsibility, hal ini menyangkut tentang kesempatan dan kejelasan tanggung jawab dari suatu tugas/pekerjaan. Seseorang sulit bekerja baik apabila ia tidak berkesempatan atau ia tidak berkesempatan atau ia tidak memperoleh tanggung jawab dari suatu tugas/pekerjaan. Demikian halnya, apabila seseorang tidak memiliki kejelasan tentang tanggung jawabnya terhadap suatu tugas/pekerjaannya dengan baik.

5) Advancement, hal ini menyangkut tentang keinginan, kesempatan, dan kejelasan kebijakan yang berhubungan dengan usaha pengembangan diri pegawai/karyawan.

Disini lain Kinerja merupakan suatu fungsi dari motivasi dan kemampuan. Untuk menyelesaikan tugas atau pekerjaan seseorang sepatutnya memiliki derajat kesediaan dan tingkat kemampuan tertentu. Kesediaan dan keterampilan seseorang tidaklah cukup untuk mengerjakan sesuatu pemahaman yang jelas tentang apa yang akan dikerjakan dan bagaimana mengerjakannya. Pegawai yang berkualitas 
akan selalu memberikan kinerja terbaik untuk keberhasilan pekerjaannya maupun untuk instansinya, pegawai perlu memahami makna dari kinerja itu sendiri. Kinerja berasal dari pengertian performance, ada pula yang memberikan pengertian performance sebagai hasil kerja atau prestasi kerja (Wibowo, 2011).

Pelaksanaan penilaian ini untuk menciptakan prestasi atau kinerja bagi pegawai sebagai sumber utama kekuatan setiap organisasi.Penilaian terhadap kinerja pegawai dalam suatu organisasi dapat dikenakan beberapa aspek (Wibowo, 2011) yaitu; kuantitas, kualitas dan ketepatan waktu. Ukuran kinerja bagi individu dapat dinyatakan dalam bentuk berikut ini:

a) Kuantitas, dinyatakan dalam bentuk jumlah output atau pekerjaan, atau presentase antara output yang aktual dengan output yang menjadi target.

b) Kualitas, dinyatakan bentuk pengawasan kualitas pekerjaan dalam batas yang dipertimbangkan untuk ditoleransi.

c) Waktu, dinyatakan dalam pencapaian batas waktu penyelesaian pekerjaan, jumlah unit pekerjaan yang dapat diselesaikan tepat waktu.

Berdasarkan indikator dan dimensi kinerja pegawai diatas,dapat disimpulkan pendapat-pendapat yang dikemukan mengenai kuantitas dan kualitas pekerjaan pegawai, ketepatan dalam bekerja harus tepat waktu, kedisplinan dalam kehadiran,berinovasi dalam bekerja,dan keakurutan antara pegawai, agar tugas dalam organisasi dapat berjalan dengan lancar dan tercapai tujuan organisasinya.

\section{Hipotesis Penelitian}

Menurut Dantes Nyoman, (2012) menyatakan hipotesis sebagai praduga atau asumsi yang harus diuji melalui data atau fakta yang diperoleh dengan jalan penelitian.

$\mathrm{Ha}$ : Ada pengaruh positif dari motivasi kerja terhadap kinerja pegawai.

Ho : Tidak ada pengaruh positif dari motivasi kerja terhadap kinerja pegawai.

\section{Metode Penelitian}

Penelitian ini dilakukan dengan menggunakan pendekatan kuantitatif. Populasi dalam penelitian ini adalah seluruh pegawai yang ada di Kantor Kecamatan TNS Kabupaten Maluku Tengah yang berjumlah 32 orang pegawai pegawai yang dijadikan sebagai responden dan tidak dilakukan penarikan sampel. Alat analisis yang digunakan untuk menjawab masalah dan tujuan penelitian adalah analisis regresi linier berganda. Sementara metode 
pengumpulan data melalui instrument kuesioner yang selanjutnya akan diuji dengan menggunakan uji validitas dan uji reliabilitas.

Penelitian ini menggunakan variabel independen dan variabel dependen, antara lain: Motivasi Kerja $(X)$ sebagai variabel independen dan Kinerja Pegawai ( $Y$ ) sebagai variabel dependen dengan indikator masing-masing sebagai berikut;

a. Indikator Motivasi Kerja sebagai berikut:

1) Achievement, hal ini menyangkut tentang dorongan dan kesempatan seseorang pegawai/karyawan untuk berprestasi pada tugas tertentu.

2) Recognition; hal ini menyangkut pengakuan dari pimpinan dan rekan sekerja.

3) Work it self, hal ini menyangkut tentang kejelasan uraian tugas dan dukungan orang lain (pimpinan dan rekan sekerja) dalam melaksanakan tugas/pekerjaan.

4) Responsibility, hal ini menyangkut tentang kesempatan dan kejelasan tanggung jawab dari suatu tugas/pekerjaan.

5) Advancement, thal ini menyangkut tentang keinginan, kesempatan, dan kejelasan kebijakan yang berhubungan dengan usaha

pengembangan diri

pegawai/karyawan.

b. Indikator Kinerja Pegawai sebagai berikut;

1) Kuantitas, Dinyatakan dalam bentuk jumlah output atau pekerjaan, atau presentase antara output yang aktual dengan output yang menjadi target.

2) Kualitas, Dinyatakan bentuk pengawasan kualitas pekerjaan dalam batas yang dipertimbangkan untuk ditoleransi.

3) Waktu, Dinyatakan dalam pencapaian batas waktu penyelesaian pekerjaan, jumlah unit pekerjaan yang dapat diselesaikan tepat waktu.

\section{Pembahasan Hasil Penelitian \\ Pengujian Instrumen}

Hasil pengujian instrument yakni validitas dengan menggunakan korelasi Product Moment data penelitian dapat dilihat pada tabel berikut ini; 


\section{Hasil Uji Validitas}

\begin{tabular}{|c|c|c|c|c|}
\hline Variabel & Item & $\begin{array}{c}\text { Koefisien } \\
\text { Korelasi }\end{array}$ & Sig. & Ket. \\
\hline \multirow{4}{*}{$\begin{array}{c}\text { Motivasi } \\
\text { Kerja } \\
(\mathrm{X})\end{array}$} & $\mathrm{X}_{1.1}$ & 0.598 & 0.000 & Valid \\
\cline { 2 - 5 } & $\mathrm{X}_{1.2}$ & 0.805 & 0.000 & Valid \\
\cline { 2 - 5 } & $\mathrm{X}_{1.3}$ & 0.437 & 0.012 & Valid \\
\cline { 2 - 5 } & $\mathrm{X}_{1.4}$ & 0.698 & 0.000 & Valid \\
\cline { 2 - 4 } & $\mathrm{X}_{1.5}$ & 0.752 & 0.000 & Valid \\
\cline { 2 - 4 } & $\mathrm{X}_{1.6}$ & 0.928 & 0.000 & Valid \\
\cline { 2 - 4 } & $\mathrm{X}_{1.8}$ & 0.781 & 0.000 & Valid \\
\cline { 2 - 4 } & $\mathrm{X}_{1.9}$ & 0.959 & 0.000 & Valid \\
\hline \multirow{4}{*}{$\begin{array}{c}\text { Kinerja } \\
\text { Pegawai } \\
(\mathrm{Y})\end{array}$} & $\mathrm{Y}_{1}$ & 0.860 & 0.000 & Valid \\
\cline { 2 - 4 } & $\mathrm{Y}_{2}$ & 0.792 & 0.000 & Valid \\
\cline { 2 - 4 } & $\mathrm{Y}_{3}$ & 0.827 & 0.000 & Valid \\
\cline { 2 - 4 } & $\mathrm{Y}_{4}$ & 0.854 & 0.000 & Valid \\
\cline { 2 - 4 } & $\mathrm{Y}_{5}$ & 0.791 & 0.000 & Valid \\
\cline { 2 - 4 } & $\mathrm{Y}_{6}$ & 0.837 & 0.000 & Valid \\
\hline
\end{tabular}

Berdasarkan hasil uji validitas diatas, terlihat bahwa seluruh pernyataan telah memenuhi kriteria koefisien korelasi 0,349 ( $r$ tabel) maka layak digunakan sebagai instrument penelitian.

Hasil pengujian instrument lainnya (uji reliabiltas) yang menggunakan Alpha Cronbach terlihat pada tabel berikut ini.

Hasil Uji Reliabilitas

\begin{tabular}{|l|c|c|}
\hline \multicolumn{1}{|c|}{ Variabel } & $\begin{array}{c}\text { Cronbach' } \\
\text { s Alpha }\end{array}$ & Ket. \\
\hline Motivasi Kerja (X1) & 0.905 & Reliabel \\
\hline Kinerja (Y) & 0.803 & Reliabel \\
\hline
\end{tabular}

Mengacu pada hasil uji reliabilitas menunjukan nilai koefisien alpha dari eluruh item pernyataan yang dijadikan sebagai instrumen masih berada di atas nilai batas (cut of value) tingkat Alpha Cronbach 0.60 berarti semua item pernyataan yang dijadikan sebagai instrumen dapat dipercaya keandalannya atau layak dan dipercaya sebagai instrumen untuk melakukan pengukuran variabel dan analisis data selanjutnya.

\section{Analisis Regresi Linier Berganda}

Pengujian dengan menggunakan regresi linier berganda untuk menjawab masalah dan tujuan penelitian dapat dilihat pada tabel berikut ini.

Hasil Uji Regresi Linier Berganda

\begin{tabular}{|c|c|c|c|c|c|}
\hline \multirow{2}{*}{ Model } & \multicolumn{2}{|c|}{$\begin{array}{c}\text { Unstand. } \\
\text { Coefficients }\end{array}$} & $\begin{array}{c}\text { Stand. } \\
\text { Coefficients }\end{array}$ & \multirow{2}{*}{ t } & \multirow{2}{*}{ Sig. } \\
\cline { 2 - 5 } & $\mathbf{B}$ & $\begin{array}{c}\text { Std. } \\
\text { Error }\end{array}$ & Beta & & \\
\hline $\begin{array}{c}\text { Constant } \\
\text { Motivasi } \\
\text { Kerja }\end{array}$ & 8.740 & 4.369 & & 2.001 & .055 \\
\cline { 2 - 5 } & .430 & .128 & .524 & 3.369 & .002 \\
\hline
\end{tabular}

Berdasarkan hasil diatas maka persamaan alanisis regresi liner berganda adalah sebagai berikut;

$Y=a+B X+e$

$Y=8.470+0.430 X+e$

Dimana;

$\begin{array}{llll}\mathrm{Y}_{2} ; & \text { Kinerja Pegawai } \\ \mathrm{X}_{1} ; & \text { Motivasi Kerja } \\ \mathrm{a} & ; & \text { Konstanta } \\ \mathrm{b} & \begin{array}{l}\text { Besarnya Koefisien Regresi } \\ \text { (parameter) }\end{array} \\ \mathrm{e} \quad ; \quad \begin{array}{l}\text { Kesalahan Pengganggu (error } \\ \text { term) }\end{array}\end{array}$

Sebagaimana diketahui bahwa nilai constatnta sebesar 8.470 mengandung arti 
bahwa nilai koefisien variabel $\mathrm{X}$ (motivasi kerja) adalah 0,430 , sementara itu coefisien regresi $\mathrm{X}$ (motivasi kerja) sebesar 8.470 menyatakan bahwa setiap perubahan $1 \%$ nilai kinerja pegawai bertambah /meningkat 0.30. Dengan demikian semakin baik lingkungan kerja maka semakin baik keinerja pegawaidengan demikian dapat dikatkan bahwa "koefisien regresi tersebut bernilai positif sehingga dapat dikatakan bahwa "pengaruh antara motivasi kerja $(X)$ dengan kinerja pegawai $(\mathrm{Y})$ adalah positif. Untuk itu interpretasinya adalh berdasarkan nilai signifikansi dari tabel coefisient Sig sebesar $0.02<0.05$ sehingga dapat disimpulkan Motivasi Kerja $(\mathrm{X})$ berpengaruh pada variabel kinerja pegawai $(Y)$.

Pengujian hipotesis apakah ada pengaruh atau tidak variabel bebas Motivasi Kerja (X2) terhadap varibel Kinerja (Y) signifikan terhadap kinerja pegawai pada Kantor Kecamatan TNS Kabupaten Maluku Tengah akan dilkukan secara parsial dengan menggunaakan uji t.

Sebelum kita membuktikan signifikan tidaknya pengaruh antara kedua variabel secara parsial terlebih dahulu kita harus mengetahui nilai $\mathrm{t}$ tabelnya. Dengan demikian maka untuk mengetahui nilai $\mathrm{t}$ tabel maka digunakan rumus;

$$
\begin{array}{lll}
\mathrm{t} \text { tabel } & ; & \mathrm{t}(\mathrm{a} / 2 ; \mathrm{n}-\mathrm{k}-1 \\
\mathrm{a} & \vdots & \text { tingkat keperayaan } \\
\mathrm{n} & ; & \text { sampel (reponden) }
\end{array}
$$

$$
\text { k } \quad \text {; jumlah variabel }
$$

Sehingga,

$$
\begin{aligned}
\mathrm{t} \text { tabel } & =0.05 / 2 ; 32-1-1 \\
& =0.025: 32-2 \\
& =0.025 ; 30 \\
& =2.042
\end{aligned}
$$

Setelah itu untuk dapat membuktikan signifikan tidaknya pengaruh antara kedua variabel maka nilai signifikansi $t$ (tsig) $<a$ 0.05 atau t hitung $(3.369>2.042$ ( $t$ tabel) maka variabel bebas tersebut berpengaruh nyata terhadap variabel terikat. Sebaliknya, apabila $\mathrm{t} t \mathrm{tsig}>\mathrm{a} 0.05$ atau $\mathrm{t}$ hitung $<\mathrm{t}$ tabel maka variabel bebas tersebut berpengaruh terhadap variabel terikat.

Sementara itu hasil pengujian hipotesis pengaruh motivasi kerja terhadap kinerja pegawai pada kantor Kantor Kecamatan TNS Kabupaten Maluku Tengah dapat dibuktikan dengan nilai signifikansi t (tsig) sebesar $=0.000$ yang berarti lebih kecil dari $a=0.05$ (tsig $0.002<0.05$ ) dan t hitung 3,396 lebih besar dari t tabel 2.042 (3.369 > 2.042). Hal ini berarti bahwa variabel motivasi kerja $(X)$ berpengaruh secara signifikan terhadap kinerja pegawai $(\mathrm{Y})$,

Motivasi menggambarkan keadaan dalam pribadi seseorang yang mendorong keinginan individu untuk melaksanakan kegiatan-kegiatan untuk mencapai tujuan. 
Pemberian motivasi juga berarti memberikan kesempatan kepada pegawai untuk mampu mengembangkan kemampuannya dan merupakan dorongan semaksimal mungkin pegawai untuk menunjukkan kinerja terbaik.

Lebih lanjut menyatakan bahwa motivasi adalah sebagai penuntun bagaimana seseorang pegawai berperilaku kerja dalam suatu organisasi; motivasi kerja dapat menjadi penuntun bagaimana seorang pegawai menentukan tingkat usaha kerja yang akan ia lakukan, dan motivasi kerja juga adalah menjadi penentu atau penuntun seseorang pegawai dalam menentukan tingkat intensitasnya dalam mengatasi berbagai hambatan atau tantangan dalam melaksanakan suatu tugas atau pekerjaan.

Dengan motivasi yang tinggi akan cenderung lebih berusaha untuk meraih sukses dari orang yang mempunyai motivasi, baik yang berasal dari diri sendiri maupun dari orang lain. Dengan demikian dapat disimpulkan bahwa motivasi kerja memiliki hubungan erat terhadap kinerja pegawai, artinya semakin tinggi motivasi kerja pegawai maka diharapkan pencapaian kinerja semakin tinggi pula.

\section{DAFTAR PUSTAKA}

Anwar Prabu Mangkunegara. (2013). Manajemen Sumber Daya Manusia Perusahaan. Bandung: PT. Remaja Rosda Karya.

Dantes Nyoman. (2012). Metode Penelitian. Yogyakarta: Andi Offset.

Eduard Y. Tamaela \& V. R. Pattipeilohy. (2015). Analisa Pengaruh Kepemimpinan dan Motivasi Kerja Terhadap Tingkat Loyalitas Karyawan (Kajian Persepsi Karyawan PT. Asuransi Bumi Putera Cabang Ambon). Siwalima Jurnal Humaniora, 3(2), 17-24.

Retrieved from www.hekaleka.org

Fred Luthans. (2002). Organizational Behavior: 7th Edition. McGraw-Hill Inc. Omolo, P. A. (2015). Effect of Motivation on Employee Performance of Commercial Banks in Kenya: A Case Study of Kenya Commercial Bank in Migori County. International Journal of Human Resource Studies, 5(2), 87. https://doi.org/10.5296/ijhrs.v5i2.7504 Sugiyono. (2012). Metode Penelitian Kuantitatif Kualitatif dan $R \& D$. Bandung: Alfabeta.

Tamaela Eduard \& Surijadi Herman. (2014). Analisis Hubungan Kausalitas Budaya Kerja, Kepuasan Kerja dan Kinerja Karyawan RSUD. Dr. Haullussy Ambon. Benchmark (Jurnal Ekonomi, Bisnis Dan 
Akuntansi), 3(1), 93-106. Retrieved

from www. Ipebmaluku.org

Wibowo. (2011). Manajemen Kinerja Edisi Ketiga (3rd ed.). Retrieved from http://kin.perpusnas.go.id/DisplayData. aspx?pId=30707\&pRegionCode=TRUN OJOYO\&pClientId=639 